\title{
In Vitro Yield of Microbial-N from Fermentation of Glucogenic and Lipogenic Diets Provided by Different Sources of Rumen Degradable Amino Acids
}

\author{
Behnaz Eyni, Mohsen Danesh Mesgaran*, Alireza Vakili and Reza Valizadeh \\ Department of Animal Science, Ferdowsi University of Mashhad, Iran
}

\begin{abstract}
This experiment was conducted to evaluate the effects of different sources of rumen degradable amino acids, soybean meal versus a commercial source of hydrolyzed cottonseed cake with low molecular weight (Fortid $\left.{ }^{\circledR}\right)$, on the in vitro ruminal fermentation responses and the microbial nitrogen yield of glucogenic $(n=8)$ and lipogenic $(n=8)$ diets. An in vitro gas production technique was used to determine the differences in microbial nitrogen yield of the diets. Sources of grain including barely and corn were used in the glucogenic diets as grinded or steam flaked, while in the lipogenic diets, corn silage, sugar beet pulp, linseed and prill fat were used to provide the energy needed for rumen fermentation. The experiment was a randomized design including two types of diets $\times$ two sources of rumen degradable amino acids factorial arrangement. The gas produced from the fermentable fraction (b) was higher for the lipogenic diets containing corn silage and $F$ than those for the others. The fraction (b) and microbial nitrogen to diet nitrogen ratio were greater $(p<0.05)$ for Fortid ${ }^{\circledR}$ versus soybean meal. The true substrate digestibility of glucogenic diets were significantly higher $(p<0.05)$ compared to those of lipogenic diets. Both the grain sources used as steam flaked caused an increase in the rate of gas produced (c) and microbial nitrogen to diet nitrogen ratio. There were significant interactions $(p<0.005)$ of the type of diets with either soybean meal or Fortid ${ }^{\circledR}$ on microbial nitrogen to diet nitrogen. The results indicated that pre-hydrolyzed protein sources which are rich in low molecular weight peptides may be considered as candidates to improve rumen feed fermentation and microbial nitrogen production with both glucogenic and lipogenic diets. This conclusion was arrived at from the different patterns of action of soybean meal and Fortid ${ }^{\circledR}$ in the present in vitro rumen fermentation responses.
\end{abstract}

Keywords: Microbial N; Glucogenic; Lipogenic; Amino acid

Abbreviations: G: Glucogenic; L: Lipogenic; SB: Soybean meal; F: Fortid $^{\star}$ (a commercial protein source rich in low molecular weight peptide provided by hydrolyzed cottonseed cake, Mytech@); B: Barely; C: Corn; Gr: Grinded; SF: Steam flaked; CS: Corn silage; FP: Fat prill fat; LS: Linseed; SBP: Sugar beet pulp; BF: Barely grounded+Fortid ${ }^{\circledR}$; BSB: Barely grounded+soybean meal; SFBF: Barely steam flaked+Fortid ${ }^{\circ}$; SFBSB: Barely steam flaked+soybean meal; CF: Grounded corn+Fortid'; CSB: Grounded corn+soybean meal; SFCF: Steam flaked corn+Fortid ${ }^{\oplus}$; SFCSB: Steam flaked corn+soybean meal; CSF: Corn silage+Fortid ${ }^{\circ}$; CSSB: Corn silage+soybean meal; LF: Linseed+Fortid ${ }^{\circ}$; LSB: Linseed+soybean meal; SBPF: Sugar beet pulp+Fortid ${ }^{\oplus}$; SBPSB: Sugar beet pulp+soybean meal; FPF: Prilled fat+Fortid ${ }^{\circ}$; FPSB: Prilled fat+soybean meal.

\section{Introduction}

All feedstuffs eaten by ruminants are first exposed to digestive activity in the rumen, the site of microbial fermentation of dietary components [1]. Dietary protein is divided into rumen-degradable (RDP) and non-degradable protein (RUP) with RDP compounds of non-protein and true protein- $\mathrm{N}$ in which true protein is degraded to peptides and rumen degradable amino acids (RDAA), and finally deaminated into ammonia- $\mathrm{N}$ or incorporated into microbial nitrogen [2]. Supplying more microbial nitrogen to the small intestine may reduce the requirement to supplement a diet with additional RUP sources; up to half of the amino acids absorbed by ruminants, and often two-thirds to three-quarters coming from microbial nitrogen [3]. Therefore, in ruminants, microbial nitrogen supply by the rumen to the small intestine must be considered as an important AA source. Ruminal microbial nitrogen synthesis depends on the supply of sufficient amounts and the type of carbohydrate as an energy source for the synthesis of peptide bonds [2]. It has been concluded that the amount of microbial nitrogen production may be influenced by the type of RDP and nonfiber carbohydrate (NFC). This may provide $30 \%$ to $45 \%$ of the diet on a dry matter basis. Different types of NFC have been shown to differ in the yields of microbial nitrogen from their in vitro fermentation [4].

Processing is necessary to increase the total-tract utilization of starch from grains; grains over-processing could cause an ample amount of digested starch in the rumen and maximize microbial nitrogen production flow to the small intestine. Bacteria of the rumen may be incorporated straight into amino acids and peptides from the diet [5]. Consequently, there is need to consider the proportion of peptides and amino acids in dairy cow rations. Peptides are intermediates in the transformation of protein to ammonia in the rumen, and their accumulation depends on the nature of diets [6]. The effects of starch source, dietary protein degradability, and their interactions on ruminal variables and cow behavior have been declared. The results of previous studies have shown that the addition of amino acids or peptides in the rumen significantly enhances microbial growth [7]. Therefore, it is hypothesized that the difference in ruminal fermentation and microbial synthesis between glucogenic and lipogenic diets may also be affected

*Corresponding author: Mohsen Danesh Mesgaran, Faculty of Agriculture, Department of Animal Science, Ferdowsi University of Mashhad 098513, Iran, Tel: +985138805000; E-mail: danesh@um.ac.ir

Received May 31, 2017; Accepted June 19, 2017; Published June 21, 2017

Citation: Eyni B, Mesgaran MD, Vakili A, Valizadeh R (2017) In Vitro Yield of Microbial-N from Fermentation of Glucogenic and Lipogenic Diets Provided by Different Sources of Rumen Degradable Amino Acids. J Vet Sci Technol 8: 453. doi: 10.4172/2157-7579.1000453

Copyright: (C) 2017 Eyni B, et al. This is an open-access article distributed under the terms of the Creative Commons Attribution License, which permits unrestricted use, distribution, and reproduction in any medium, provided the original author and source are credited. 
Citation: Eyni B, Mesgaran MD, Vakili A, Valizadeh R (2017) In Vitro Yield of Microbial-N from Fermentation of Glucogenic and Lipogenic Diets Provided by Different Sources of Rumen Degradable Amino Acids. J Vet Sci Technol 8: 453. doi: 10.4172/2157-7579.1000453

Page 2 of 6

by the type and the level of RDAA. To the best of our knowledge, no previous study has implemented the effect of RDAA in glucogenic and lipogenic diets on in vitro microbial nitrogen production. According to this framework, the first aim of our research was to evaluate whether predigestion and production of peptide have an effect on microbial nitrogen production. The second objective of this experiment was to determine the kinetic parameters of gas production and microbial nitrogen production of glucogenic and lipogenic diets with different providers of amino acid sources; soybean meal versus Fortid" (hydrolyzed protein from cottonseed cake).

\section{Materials and Methods}

\section{Experimental diets}

The experimental diets are shown in Table 1 . The study was carried out by using two types of diets known as glucogenic $(\mathrm{G})$ and lipogenic (L), sources of rumen and highly degradable amino acids including soybean meal (SB) and Fortid (a commercial protein source rich in low molecular weight peptide provided by hydrolyzed cottonseed

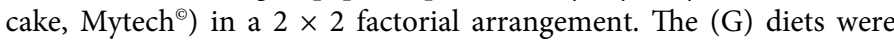
provided by the inclusion of two sources of grains including barely (B) and corn $(\mathrm{C})$ used as grinded $(\mathrm{Gr})$ or steam flaked (SF). To prepare the (L) diets, feed sources with high concentration of NDF including corn silage (CS) or fat (prill fat (FP) and linseed (LS)) or pectin (sugar beet pulp (SBP)) were used. Therefore, the glucogenic diets $(n=8)$ were barely grounded+Fortid" (BF), barely grounded+soybean meal (BSB), barely steam flaked+Fortid $(\mathrm{SFBF})$, barely steam flaked+soybean meal (SFBSB), grounded corn+Fortid $(\mathrm{CF})$, grounded corn+soybean meal (CSB), steam flaked corn+Fortid (SFCF), steam flaked corn+soybean meal (SFCSB); and the lipogenic diets $(n=8)$ were corn silage+Fortid (CSF), corn silage+soybean meal (CSSB), linseed+Fortid (LF), linseed+soybean meal (LSB), sugar beet pulp+Fortid (SBPF), sugar beet pulp+soybean meal (SBPSB), prilled fat+Fortid ${ }^{\circ}$ (FPF), prilled fat+soybean meal (FPSB).

\section{In vitro rumen fermentation and microbial nitrogen production}

In order to evaluate the rumen fermentation responses and microbial nitrogen production, an in vitro experiment was conducted using the gas technique. Rumen inoculum was collected from three rumen-fistulated Holstein lactating dairy cows $(620 \pm 5 \mathrm{~kg} \mathrm{BW}, 300 \pm$ 5 DIM, mean \pm SD) Prior to the morning feeding, fed with $3.2 \mathrm{~kg}$ of dry matter (DM) corn silage, $5.1 \mathrm{~kg} \mathrm{DM}$ alfalfa hay and $12.8 \mathrm{~kg}$ of DM concentrate (containing: $24 \%$ corn grains, $20.5 \%$ barley grains, $27.1 \%$ soybean meal, $13.8 \%$ canola meal, $13.8 \%$ wheat bran, $0.3 \%$ calcium carbonate, $0.5 \%$ mineral and vitamin premix). The ruminal content was quickly filtered through four layers of cheese cloth to remove larger feed bits, and then moved to the laboratory. A sample of each experimental diet was weighed $(250 \mathrm{mg})$, and then placed in a $125 \mathrm{ml}$ serum bottle, replicated for four times and ran thrice. After that, the filtrate was used

\begin{tabular}{|c|c|c|c|c|c|c|c|c|c|c|c|c|c|c|c|c|}
\hline & \multicolumn{8}{|c|}{ Glucogenica } & \multicolumn{8}{|c|}{ Lipogenic } \\
\hline & $\mathrm{BF}$ & BSB & SFBF & SFBSB & $\mathrm{CF}$ & CSB & SFCF & SFCSB & LF & LSB & SBPF & SBPSB & CSF & CSSB & FPF & FPSB \\
\hline Corn silage & 12.77 & 12.77 & 12.77 & 12.77 & 12.84 & 12.84 & 12.84 & 12.84 & 20.03 & 20.03 & 19.87 & 19.87 & 22.88 & 22.88 & 18.18 & 18.18 \\
\hline Alfalfa hay & 26.45 & 26.45 & 26.45 & 26.45 & 26.59 & 26.59 & 26.59 & 26.59 & 36.01 & 36.01 & 34.91 & 34.91 & 37.16 & 37.16 & 35.95 & 35.95 \\
\hline Corn grain & 14.43 & 14.43 & 14.43 & 14.43 & 23.51 & 23.51 & 0 & 0 & 10.89 & 10.89 & 9.35 & 9.35 & 11.03 & 11.03 & 10.87 & 10.87 \\
\hline Barely grain & 24.54 & 24.54 & 0 & 0 & 14.71 & 14.71 & 14.71 & 14.71 & 11.05 & 11.05 & 9.49 & 9.49 & 11.21 & 11.21 & 11.03 & 11.03 \\
\hline Steam flaked corn & 0 & 0 & 0 & 0 & 0 & 0 & 23.51 & 23.51 & 0 & 0 & 0 & 0 & 0 & 0 & 0 & 0 \\
\hline Steam flaked barely & 0 & 0 & 24.54 & 24.54 & 0 & 0 & 0 & 0 & 0 & 0 & 0 & 0 & 0 & 0 & 0 & 0 \\
\hline Weat bran & 7.63 & 7.63 & 7.63 & 7.63 & 7.67 & 7.67 & 7.67 & 7.67 & 7.62 & 7.62 & 4.38 & 4.38 & 4.39 & 4.39 & 11.24 & 11.24 \\
\hline Fortid $($ ) & 5.89 & 0 & 5.89 & 0 & 5.92 & 0 & 5.92 & 0 & 6.62 & 0 & 6.01 & 0 & 5.61 & 0 & 7.31 & 0 \\
\hline XPS(Yasminomax®)b & 3.48 & 3.48 & 3.48 & 3.5 & 3.5 & 3.5 & 3.5 & 3.5 & 3.48 & 3.48 & 3.79 & 3.79 & 3.8 & 3.8 & 3.84 & 3.84 \\
\hline Soybean meal & 0 & 5.89 & 0 & 5.92 & 0 & 5.92 & 0 & 5.92 & 0 & 6.62 & 0 & 6.01 & 0 & 5.61 & 0 & 7.31 \\
\hline Canola meal & 4.81 & 4.81 & 4.81 & 0 & 5.25 & 0 & 5.25 & 0 & 0 & 4.3 & 3.48 & 0 & 3.93 & 0 & 0 & 0 \\
\hline Linseed & 0 & 0 & 0 & 0 & 0 & 0 & 0 & 0 & 4.3 & 0 & 0 & 8.72 & 0 & 0 & 0 & 0 \\
\hline Sugar beet pulp & 0 & 0 & 0 & 0 & 0 & 0 & 0 & 0 & 0 & 0 & 8.72 & 0 & 0 & 0 & 0 & 1.57 \\
\hline Fat prill & 0 & 0 & 0 & 0 & 0 & 0 & 0 & 0 & 0 & 0 & 0 & 0 & 0 & 0 & 1.57 & 0 \\
\hline CP $(\%)$ & 17.5 & 17.5 & 17.5 & 17.5 & 17.5 & 17.5 & 17.5 & 17.5 & 17.6 & 17.6 & 17.5 & 17.5 & 17.5 & 17.5 & 17.5 & 17.5 \\
\hline NDF (\%) & 33.8 & 33.8 & 33.8 & 33.8 & 32.6 & 32.6 & 32.6 & 32.6 & 38.7 & 38.7 & 40.1 & 40.1 & 39 & 39 & 38.3 & 38.3 \\
\hline NFC (\%) & 42 & 42 & 42 & 42 & 43.7 & 43.7 & 43.7 & 43.7 & 35.4 & 35.4 & 36.5 & 36.5 & 35.8 & 35.8 & 35.1 & 35.1 \\
\hline $\mathrm{ME}(\mathrm{mg} / \mathrm{kg})$ & 2.51 & 2.51 & 2.51 & 2.51 & 2.5 & 2.5 & 2.5 & 2.5 & 2.53 & 2.53 & 2.47 & 2.47 & 2.48 & 2.48 & 2.55 & 2.55 \\
\hline
\end{tabular}

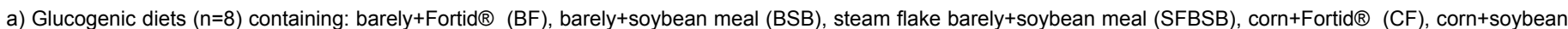
meal

(CSB), steam flake corn+Fortid (SFCF), steam flake corn+soybean meal (SFCSB), and lipogenic diets containing: corn silage+Fortid $(C S F)$ corn silage+soybean meal (CSSB), linseed+Fortid $\AA$ (LF), linseed+soybean meal (LSB), sugar beet pulp+Fortid $\AA$ (SBPF), sugar beet pulp soybean meal (SBPSB), prilled fat+Fortid ${ }^{\circ}$ (FPF), and prilled fat soybean meal (FPSB); b) XPS: xylose protected soybean (Yasminomax®) meal containing (DM: 93\%, NDF: 12.7\%, ADF: 13.4\%, CP: 53.4\%, Ash: 8.36\%, EE: $8.16 \%$ ) was provided from Iranian local company named Yasnamehr

Table 1: Ingredients (\% DM), chemical composition and energy content of the experimental diets. 
Citation: Eyni B, Mesgaran MD, Vakili A, Valizadeh R (2017) In Vitro Yield of Microbial-N from Fermentation of Glucogenic and Lipogenic Diets Provided by Different Sources of Rumen Degradable Amino Acids. J Vet Sci Technol 8: 453. doi: 10.4172/2157-7579.1000453

Page 3 of 6

for in vitro gas test described in detail by Grings et al. [8]. Cumulative gas production was measured at 2, 4, 6, 8, 10, 12, 24, 48, 72 and 96 hours of the incubation time. After the deduction of gas production from blank bottles, the data were fitted to an exponential model: $\mathrm{y}=\mathrm{A} \times$ $\left(1-\mathrm{e}^{-\mathrm{ct}}\right)$ [9], where (y) is the cumulative volume of the gas produced at time $\mathrm{t}(\mathrm{h}),(\mathrm{A})$ is the asymptotic gas volume $(\mathrm{ml} / 250 \mathrm{mg} \mathrm{DM})$, and $(\mathrm{c})$ is the fractional constant rate $(\mathrm{ml} / \mathrm{h})$. The halftime of gas production $\left(t_{1 / 2}\right)$ was calculated as $\mathrm{t}_{1 / 2}=\ln 2 / c$ after the first 96-hour gas run, and then a second incubation with the diets as substrates was performed to obtain the degradability measures at substrate-specific times (i.e., $t_{1 / 2}$ for each substrate) [10]. The incubations were stopped at the diet-specific $t_{1 / 2}$ and the microbial $\mathrm{N}$ production at $t_{1 / 2}$ was determined in accordance with Grings [8] by using the " $\mathrm{N}$ balance" equation, which is given as follows:

\section{Microbial N Production at $t_{1 / 2}=\operatorname{Diet} \mathrm{N}+\Delta \mathrm{NH}_{3}-\mathrm{N}-\mathrm{NDFN}$ at $t_{1 / 2}$}

True substrate degradability was determined and calculated at $t_{1 / 2}$ [11]. The conversion of dietary $\mathrm{N}$ to microbial nitrogen (MN/DN) was determined by microbial nitrogen divided by dietary nitrogen. The concentrations of Ammonia-N per dietary nitrogen (Ammonia/ $\mathrm{DN}$ ) and ammonia-N+MN per dietary nitrogen (Ammonia+MN/ $\mathrm{DN}$ ) were measured as the rate of conversion of $\mathrm{N}$ to ammonia $\mathrm{N}$ and microbial-N in the rumen.

\section{Chemical composition}

A chemical analysis was conducted according to AOAC (2000). All the feed samples were grounded to pass through a $2 \mathrm{~mm}$ screen, and then analyzed for dry matter $\left(135^{\circ} \mathrm{C}\right.$ for 24 hours as per method 930.15$)$, ash $\left(535^{\circ} \mathrm{C}\right.$; method 942.05$)$, CP (method 990.03$)$, and ether extract (method 920.39) [12]. The method used to evaluate acid detergent and neutral detergent fibers (NDF and ADF, respectively) were based on Van Soest [13]. Sodium sulfite and heat stable alpha amylase were not used in the NDF and ADF assays, and were expressed without residual ash. Nitrogen fractionation was carried out as described by Higgs et al. [14]. Briefly, the proteins of SBM and Fortid were divided into five fractions, namely $A_{1}, A_{2} B_{1}, B_{2}$ and $C$. The $A_{1}$ fraction is made up of ammonia, and calculated by: Ammonia $\times(\mathrm{SP} / 100) \times(\mathrm{CP} / 100)(\%$ of $\mathrm{CP}$ ); where SP is the soluble protein and $\mathrm{CP}$ is the crude protein. The fraction $\mathrm{A}_{2}$ refers to soluble true protein and is rapidly degraded in the rumen; it is derived by: $\left(\mathrm{SP} \times \mathrm{CP} / 100-\mathrm{A}_{1}\right)$, with all of them based on the percentage of $C P$. The fraction $B_{1}$ refers to insoluble true protein, and it is obtained by the difference between $\mathrm{CP}$ and $\left(\mathrm{A}_{1}-\mathrm{A}_{2}-\mathrm{B}_{2}-\mathrm{C}\right)$. The fiber-bound protein or fraction $\mathrm{B}_{2}$ is obtained by: (NDICP-ADICP) $\times$ $\mathrm{CP} / 100$. Finally, the fraction $\mathrm{C}$ or indigestible protein is calculated as $(\mathrm{ADICP} \times \mathrm{CP} / 100)$.

\section{Calculations and statistical analyses}

The treatments were arranged as a randomized design including two types of diets $(\mathrm{G}$ and $\mathrm{L}) \times$ two sources of RDAA $(\mathrm{SB}$ and $\mathrm{F})$ in a factorial arrangement, as per the following statistical model:

\section{$Y i j k=\mu+\alpha i+\beta j+(\alpha \beta) i j+e i j k Y i j k$,}

when $\alpha$ is the main effect of diet, $\beta$ is the main effect of $\mathrm{CP}$ source, and $\alpha \beta$ is the interaction between them.

The data from gas production were statistically analyzed by using the general linear model's procedures of SAS 9.1 [15]. The differences between the means were assessed by the Duncan test at $p \leq 0.05$. Predesigned contrasts were used to compare the groups of treatments. The results when the contrast between the factors was significant are shown in Tables 3 and 4 . The comparisons between corn silage and sugar beet pulp containing diets, prill fat versus linseed containing diets, and steam flaked corn and steam flaked barely were not significant, and therefore not shown in the tables.

\section{Results}

In this study, nitrogen fractionation was used to present the rumen degradation parameters of the amino acids used in the experimental diets. The data for the nitrogen fractionation of SB and F, according to CNCPS (version 6.5) protocols, are presented in Table 2. Fraction $A_{2}$ was significantly higher in $\mathrm{F}$ compared to that in $\mathrm{SB}(\mathrm{p}<0.05)$; however, fractions $\mathrm{B}_{1}, \mathrm{~B}_{2}$ and $\mathrm{C}$ were higher in $\mathrm{SB}$ than in $\mathrm{F}\left(\mathrm{A}_{2}\right.$ in $\mathrm{F}$ was 4.56 folds higher than in $\mathrm{SB}$, while $\mathrm{B}_{2}$ and $\mathrm{C}$ were 7.8 and 2.62 folds higher in $\mathrm{SB}$ than in $\mathrm{F}$, respectively).

The means of the gas produced ( $\mathrm{ml}$ per $250 \mathrm{mg} \mathrm{DM}$ ) from the experimental diets are shown in Figure 1. As observed, the volume of produced gas was maximum for BF and minimum for FPSB. The in vitro gas production parameters including the gas produced from the fermentable part (b), the constant rate of gas production (c), and halftime $\left(\mathrm{t}_{1 / 2}\right)$ are presented in Table 3 . The main effects of RDAA and the types of diets on the (b) fraction were significant $(p<0.01)$, and the main effects of RDAA and the types of diets were significant regarding the parameters $(c)$ and $\left(t_{1 / 2}\right)$. There was no interaction between RDAA and the diets regarding $(\mathrm{b}),(\mathrm{c})$ and $\left(\mathrm{t}_{1 / 2}\right)$. The contrasts between $\mathrm{G}$ and $\mathrm{L}$, and $\mathrm{SB}$ and $\mathrm{F}$ showed significant differences between the types of diets and source of RDAA used in the present study regarding the parameter (b) $(p<0.05)$. The contrasts between the types of diets, source of RDAA and forms of the grain used in the experimental diets were significant $(\mathrm{p}<0.05)$ for the parameter $(\mathrm{c})$ and the halftime of gas production $\left(\mathrm{t}_{1 / 2}\right)$. In total, parameter (b) in the $\mathrm{G}$ diets was considerably higher than that in the $\mathrm{L}$ diets $(\mathrm{P}<0.05)$. The parameter $(\mathrm{b})$ tended to be different among the treatments, with the highest values observed in CSF and the lowest values in FPSB $(p<0.05)$. The $(c)$ parameter of SFBSB was the greatest among all the diets $(\mathrm{p}<0.05)$, resulting in a significantly lower halftime of maximal gas production $t_{1 / 2}(p<0.05)$ for these diets.

The means of TSD, (MN/DN), (Ammonia/DN) and $($ Ammonia $+\mathrm{MN} / \mathrm{DN})$ in the types of the experimental diets, which are calculated from the incubation of the sample for $t_{1 / 2}$ using the gas test technique, are given in Table 4 . In the case of TSD, the main effect of RDAA and diet was significant $(p<0.01)$. All the main effects and interactions between RDAA and diets were significant for $A+M N$ / $\mathrm{DN}$ and $\mathrm{MN} / \mathrm{ND}$. The main effect of diet was significant $(\mathrm{p}<0.01)$ for ammonia-N/DN. All the contrasts between G and L, and SB and $\mathrm{F}$ regarding TSD were significant $(\mathrm{p}<0.05)$. The glucogenic diets also had greater significant in vitro DM digestibility $(\mathrm{p}<0.05)$ compared to the others. The $(\mathrm{MN} / \mathrm{DN})$ of the diets were significantly influenced by the type of diets, RDAA and physical form of the grain used in the study $(\mathrm{p}<0.05)$. The contrasts between $\mathrm{G}$ and $\mathrm{L}$, and SB and F and the physical type of grain showed significant differences between the types of diets, sources of RDAA, and the physical type of grain in the present study regarding $(A m m o n i a+M N / D N)(p<0.01)$. The $(M N / D N)$ was the minimum in the CSSB and the FPSB diets, and it was the maximum

\begin{tabular}{|c|c|c|c|c|}
\hline & Soybean meal & Fortid® & SEM & p value \\
\hline A1 & 0 & 0 & 0 & - \\
A2 & 14.42 & 65.78 & 0.82 & $<0.001$ \\
B1 & 33.94 & 25.34 & 1.18 & 0.002 \\
B2 & 42.75 & 5.48 & 2.88 & 0.001 \\
C & 8.87 & 3.38 & 1.88 & 0.02 \\
\hline
\end{tabular}

Table 2: Nitrogen fractionation (CNCPS, version 6.5) of soybean meal and Fortid ${ }^{\circledR}$. 
Citation: Eyni B, Mesgaran MD, Vakili A, Valizadeh R (2017) In Vitro Yield of Microbial-N from Fermentation of Glucogenic and Lipogenic Diets Provided by Different Sources of Rumen Degradable Amino Acids. J Vet Sci Technol 8: 453. doi: 10.4172/2157-7579.1000453

Page 4 of 6

\begin{tabular}{|c|c|c|c|c|c|c|c|c|c|c|c|c|c|c|c|c|c|c|c|c|c|c|c|}
\hline & \multicolumn{8}{|c|}{ glucogenic ${ }^{a)}$} & \multicolumn{8}{|c|}{ Lipogenic } & \multirow[t]{4}{*}{ SEM } & \multicolumn{6}{|c|}{ P-value } \\
\hline & \multicolumn{4}{|c|}{ Soybean meal } & \multicolumn{4}{|c|}{ Fortid $^{\circledR}$} & \multicolumn{4}{|c|}{ Soybean meal } & \multicolumn{4}{|c|}{ Fortid $^{\circledR}$} & & & & & & & \\
\hline & \multirow[b]{2}{*}{ BSB } & \multirow[b]{2}{*}{ SFBSB } & \multirow[b]{2}{*}{ CSB } & \multirow[b]{2}{*}{ SFCSB } & \multirow[b]{2}{*}{$\mathrm{BF}$} & \multirow[b]{2}{*}{ SFBF } & \multirow[b]{2}{*}{ CF } & \multirow[b]{2}{*}{ SFCF } & \multirow[b]{2}{*}{ LSB } & \multirow[b]{2}{*}{ SBPSB } & \multirow[b]{2}{*}{ CSSB } & \multirow[b]{2}{*}{ FPSB } & \multirow[b]{2}{*}{ LF } & \multirow[b]{2}{*}{ SBPF } & \multirow[b]{2}{*}{ CSF } & \multirow[b]{2}{*}{ FPF } & & \multirow[b]{2}{*}{$D^{c)}$} & \multirow[b]{2}{*}{ RDAA } & \multirow{2}{*}{$D \times R D A A$} & \multicolumn{3}{|c|}{ Contrast } \\
\hline & & & & & & & & & & & & & & & & & & & & & $1^{\text {b) }}$ & 2 & 3 \\
\hline$b^{d)}$ & 83.07 & 77.61 & 81.31 & 78.02 & 104.30 & 101.0 & 103.64 & 101.89 & 72.88 & 72.79 & 79.04 & 52.6 & 90.97 & 99.86 & 105.49 & 74.34 & 1.8 & $* *$ & ** & ns & ** & ** & ns \\
\hline $\mathrm{c}$ & 0.06 & 0.1 & 0.05 & 0.09 & 0.05 & 0.05 & 0.04 & 0.05 & 0.07 & 0.06 & 0.07 & 0.09 & 0.05 & 0.05 & 0.05 & 0.04 & 0.002 & ns & $* *$ & ns & ** & ** & ** \\
\hline$t_{1 / 2}$ & 11.5 & 6.7 & 13.7 & 7.2 & 14.3 & 14.8 & 15.5 & 15.0 & 9.9 & 10.8 & 9.9 & 7.5 & 14.4 & 15.1 & 14.8 & 15.3 & 0.29 & ns & $* *$ & ns & $* *$ & ** & ** \\
\hline
\end{tabular}

a) Glucogenic diets $(n=8)$ containing: barely+Fortid $(B F)$, barely+soybean meal $(B S B)$, steam flake barely+soybean meal $(S F B S B)$, corn+Fortid ${ }^{\circledR}(C F)$, corn+soybean meal (CSB), steam flake corn+Fortid ${ }^{\otimes}$ (SFCF), steam flake corn+soybean meal (SFCSB), and lipogenic diets containing: corn silage+Fortid ${ }^{\circledR}$ (CSF) corn silage+soybean meal (CSSB), linseed+Fortid ${ }^{\circledR}$ (LF), linseed+soybean meal (LSB), sugar beet pulp+Fortid ${ }^{\circledR}$ (SBPF), sugar beet pulp soybean meal (SBPSB), prilled fat+Fortid ${ }^{\circledR}$ (FPF), and prilled fat soybean meal (FPSB); b) Contrast 1: glucogenic versus lipogenic, 2: Fortid ${ }^{\circledR}$ versus soybean meal, and 3: steam flake versus grind; c) D; Diet, RDAA: rumen degradable amino acid, D $\times$ RDAA: interaction between RDAA and D; ( $\left.{ }^{*} \mathrm{P}<0.05\right),\left({ }^{*}: \mathrm{P}<0.01\right)$, (ns: Not significant); d) Fraction b: Gas production from fermentable part (ml per 250 $\mathrm{mg}$ sample), c: gas production constant ( $\mathrm{ml} / \mathrm{h})$, TSD: true substrate digestibility $(\mathrm{mg}), \mathrm{t} 1 / 2$ : halftime of gas production $(\mathrm{h})$

Table 3: In vitro gas production parameters of experimental diet.

\begin{tabular}{|c|c|c|c|c|c|c|c|c|c|c|c|c|c|c|c|c|c|c|c|c|c|c|c|}
\hline & \multicolumn{8}{|c|}{ glucogenica) $^{\text {a }}$} & \multicolumn{8}{|c|}{ Lipogenic } & \multirow{4}{*}{ SEM } & \multirow{2}{*}{\multicolumn{6}{|c|}{ P-value }} \\
\hline & \multicolumn{4}{|c|}{ Soybean meal } & \multicolumn{4}{|c|}{ Fortid $^{\circledR}$} & \multicolumn{4}{|c|}{ Soybean meal } & \multicolumn{4}{|c|}{ Fortid $^{\circledast}$} & & & & & & & \\
\hline & \multirow{2}{*}{ BSB } & \multirow{2}{*}{ SFBSB } & \multirow{2}{*}{ CSB } & \multirow{2}{*}{ SFCSB } & \multirow{2}{*}{$\mathrm{BF}$} & \multirow{2}{*}{ SFBF } & \multirow{2}{*}{ CF } & \multirow{2}{*}{ SFCF } & \multirow{2}{*}{ LSB } & \multirow{2}{*}{ SBPSB } & \multirow{2}{*}{ CSSB } & \multirow{2}{*}{ FPSB } & \multirow{2}{*}{ LF } & \multirow{2}{*}{ SBPF } & \multirow{2}{*}{ CSF } & \multirow{2}{*}{ FPF } & & \multirow{2}{*}{$D^{c)}$} & \multirow{2}{*}{ RDAA } & \multirow{2}{*}{$\begin{array}{c}D \times \\
\text { RDAA }\end{array}$} & \multicolumn{3}{|c|}{ Constract } \\
\hline & & & & & & & & & & & & & & & & & & & & & $1^{\text {b) }}$ & 2 & 3 \\
\hline TSD & 613.33 & 570.67 & 608 & 597.33 & 777.33 & 780 & 778.67 & 758.67 & 474.67 & 673.33 & 541.33 & 342.67 & 722.67 & 738.67 & 710.67 & 729.33 & 21.50 & $* *$ & $* *$ & ns & $* *$ & $* *$ & ns \\
\hline MN/DN & 0.46 & 0.63 & 0.36 & 0.62 & 0.46 & 0.44 & 0.45 & 0.53 & 0.51 & 0.23 & 0.07 & 0.09 & 0.52 & 0.48 & 0.41 & 0.39 & 0.02 & $* *$ & ** & $* *$ & $* *$ & $* *$ & ** \\
\hline Amonia/DN & 0.45 & 0.28 & 0.50 & 0.27 & 0.47 & 0.49 & 0.48 & 0.43 & 0.44 & 0.36 & 0.49 & 0.37 & 0.47 & 0.46 & 0.47 & 0.52 & 0.02 & $* *$ & ns & ns & $* *$ & $* *$ & $* *$ \\
\hline $\mathrm{A}+\mathrm{MN} / \mathrm{DN}$ & 0.89 & 0.89 & 0.87 & 0.9 & 0.93 & 0.95 & 0.93 & 0.96 & 0.95 & 0.59 & 0.56 & 0.46 & 0.99 & 0.95 & 0.87 & 0.91 & 0.001 & $* *$ & ** & $* *$ & ** & ** & ** \\
\hline
\end{tabular}

Glucogenic diets $(n=8)$ containing: barely+Fortid ${ }^{\circledR}(B F)$, barely+soybean meal $(B S B)$, steam flake barely+soybean meal $(S F B S B)$, corn+Fortid ${ }^{\circledR}(C F)$, corn+soybean meal (CSB), steam flake corn+Fortid ${ }^{\circledR}$ (SFCF), steam flake corn+soybean meal (SFCSB), and lipogenic diets containing: corn silage+Fortid ${ }^{\circledR}$ (CSF) corn silage+soybean meal (CSSB), linseed+Fortid ${ }^{\circledR}$ (LF), linseed+soybean meal (LSB), sugar beet pulp+Fortid ${ }^{\circledR}$ (SBPF), sugar beet pulp soybean meal(SBPSB), prilled fat+Fortid ${ }^{\circledR}$ (FPF), and prilled fat soybean meal (FPSB); a) Glucogenic versus lipogenic: 1, Fortid ${ }^{\circledR}$ versus soybean meal: 2, and steam flake versus grind: 3; D; Diet, RDAA: rumen degradable amino acid, D × RDAA: interaction between RDAA and D; ( $\left.{ }^{*}: \mathrm{P}<0.05\right),\left({ }^{* *}: \mathrm{P}<0.01\right)$, (ns: Not significant)

Table 4: True substrate digestibility (TSD, mg/g), microbial nitrogen to dietary nitrogen ratio (MN/ND), ammonia-N to dietary nitrogen ratio (Ammonia/ND), Ammonia$\mathrm{N}+$ microbial nitrogen to dietary $\mathrm{N}$ ratio $(\mathrm{A}+\mathrm{MN} / \mathrm{ND})$ of experimental diet.

in SFBSB and SFCSB with more starch included, resulting in a positive effect on lower ammonia $\mathrm{N}$ concentration. The FPF diet resulted in the highest $($ Ammonia/DN $)(\mathrm{P}<0.05)$. The ratio of ammonia $\mathrm{N}+\mathrm{MN}$ to Diet $\mathrm{N}(\mathrm{A}+\mathrm{MN} / \mathrm{DN})$ had a tendency to increase in the $\mathrm{LF} \operatorname{diet}(\mathrm{P}<0.05)$. The response surface of NDF and NFC with microbial nitrogen is presented in Figure 2. When NDF was equal to 33 and NFC was equal to 36 , microbial nitrogen was found to be the greatest.

\section{Discussion}

In the current study, we used two different sources of RDAA to evaluate the rumen fermentation potential of a wide range of glucogenic and lipogenic diets. In addition, microbial-N production was also determined. In order to evaluate the degradation potential of the amino acid sources, nitrogen fractionation [14] was used. The results indicated that $\mathrm{F}$ was more rumen degradable than $\mathrm{SB}$ as fraction $\mathrm{A}_{2}$ in this amino acid provider was higher than that in SB. Fractions $B_{1}, B_{2}$ and $C$ were higher in $\mathrm{SB}$. Fraction $\mathrm{B}_{1}$ was rapidly degraded in the rumen, and some of fraction $\mathrm{B}_{2}$ was fermented in the rumen and some escaped to the lower gut [16]. Fraction $C$ could not be degraded in the rumen and did not supply amino acids post-ruminally; thereby, this result showed that $\mathrm{F}$ and $\mathrm{SB}$ were different regarding the nitrogen fractions, and $\mathrm{F}$ was more degradable than SB.

The main aim of this study was to investigate the effects of energy and type of RDAA in glucogenic and lipogenic diets on ruminal fermentability and MCP yield by using the gas production technique. As observed in Figure 1, the highest gas volume in $\mathrm{BF}$ showed that $\mathrm{F}$ was more degradable in the rumen to provide more fermentable substrate, given the fact that the gas produced is directly proportional to the rate at which the substrate is degraded [17]. The minimum gas production in FPSB might be due to the prevention of substrate availability for bacteria by prill fat or the possible toxicity of microorganisms. As expected, the amount of gas produced by $\mathrm{G}$ diets was especially higher compared to that of the L diets. This was not unexpected as a lot of in vitro studies have reported significant differences in the fermentation characteristics of various carbohydrate sources [18]. The gas produced from the fermentable part (b) and the rate of gas production (c) were affected by the sources of RDAA; (b) was $30 \%$ higher in F and (c) was $63 \%$ higher in SB containing diets. It can be seen that SB had high values for $B_{2}$ and $C$ fractions, leading to difficulties in attachment by microorganisms and causing lower gas production than F. Higher fraction (b) was observed in $G$ diets as compared to that of $L$ diets. Glucogenic dietary components were fermented in the rumen to supply energy for rumen microorganisms and produced more in vitro gas [19]. However, when grounded grain was used, parameter (b) increased while parameter (c) decreased in the SF containing diets. High rate of gas production was observed in SF, possibly influenced by the availability of rumen carbohydrate for the microbial population. The maximum rate of gas production (c) was observed in the SFBSB diet. Our results were consistent with the findings of other studies, which confirmed that steam flaking of grains led to greater production of in vitro gas compared to unprocessed grain [18]. Soluble starch of the grain in the rumen is readily susceptible to enzymatic hydrolysis, and therefore, whether amino acids and peptides can stimulate the growth of rumen bacteria, either in vitro or in vivo, will depend on the energy source [20]. The slowest gas production was observed in FPSB, indicating that prill fat was less readily available to the microbes in the rumen [21]. 

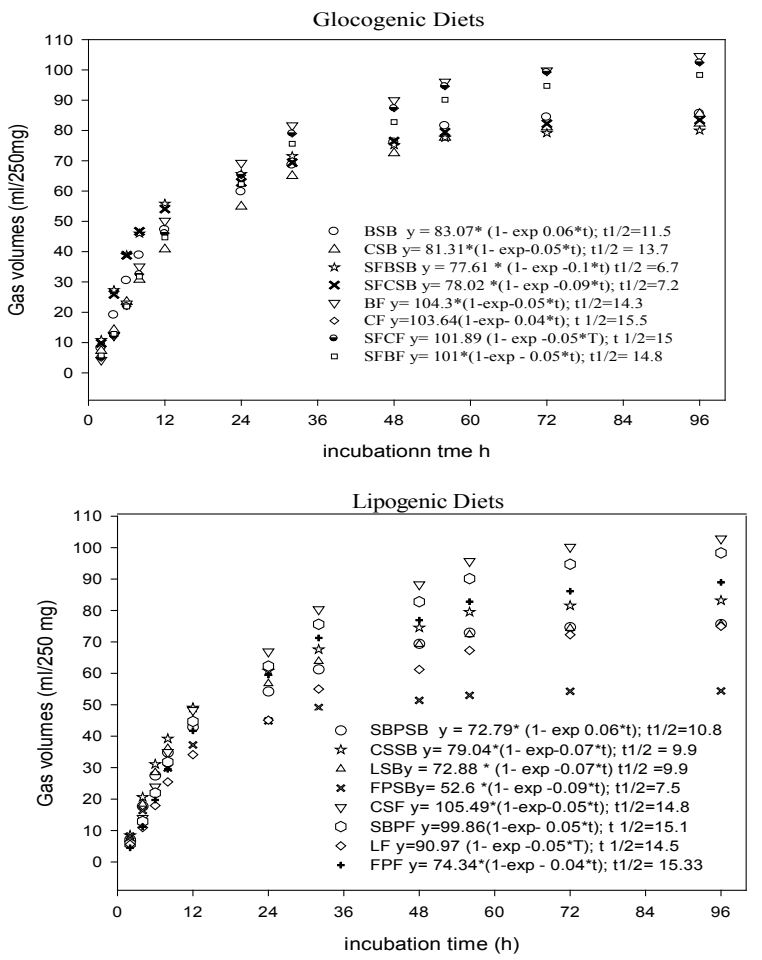

Figure 1: Gas produced ( $\mathrm{ml}$ per $250 \mathrm{mg} \mathrm{DM}$ ) from the experiment diets including 1. Glucogenic diets $(n=8)$ containing barely+Fortid ${ }^{\circledR} \quad(B F)$ barely+soybean meal (BSB), steam flake barely+soybean meal (SFBSB), corn+Fortid $^{\circledR}(C F)$, corn+soybean meal (CSB), steam flake corn+Fortid ${ }^{\circledR}(S F C F)$, steam flake corn+soybean meal (SFCSB), and lipogenic diets containing: corn silage+Fortid (CSF) corn silage+soybean meal (CSSB), linseed +Fortid ${ }^{\circledR}$ (LF), linseed+soybean meal (LSB), sugar beet pulp+Fortid ${ }^{\circledR}$ (SBPF), sugar beet pulp soybean meal (SBPSB), prilled fat+Fortid ${ }^{\circledR}(F P F)$, prilled fat soybean meal (FPSB).

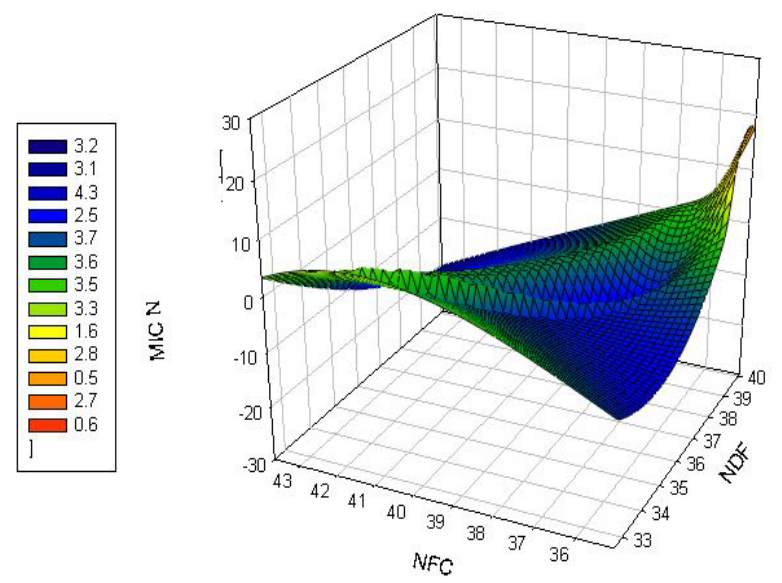

Figure 2: Response surfaces of NDF and NFC with microbial nitrogen production.

Higher TSD in the Fortid containing diets were observed. It was probably due to the high degradability of the soluble AA from $\mathrm{F}$ compared to SB [2]. Additionally, in vitro TSD were observed to have a high correlation with gas production [22], and F containing diets had higher parameter (b) than SB. There was no significant difference between SF and Gr regarding TSD. This finding is consistent with May et al. [23], whose control had higher digestibility than the SF containing treatments. Glucogenic diets had higher (11\% higher) TSD than L diets $(\mathrm{p}<0.01)$. This discrepancy was likely because of more degradability of glucogenic ingredients. It's possible that the high amount of NFC in $\mathrm{BF}$ diets was the reason behind the higher amount of TSD observed in this diet, because microbes that ferment NFC not only use $\mathrm{NH}_{3}$, but peptides as well.

Higher MN/DN, Ammonia/DN and A+MN/DN were observed in $\mathrm{F}$ than in $\mathrm{SB}$ diets $(0.46,0.47$, and 0.94 vs. $0.37,0.39$, and 0.77 , respectively), which could likely be attributed to the high degradability of $\mathrm{F}$. It can be supposed that dietary non-protein $\mathrm{N}$ will be of small advantage to the ruminant unless it is first converted into ammonia, and then utilized in the rumen for microbial protein synthesis, and the amount of non-protein $\mathrm{N}$ that can be utilized will depend upon the amount of fermentable energy available for microbial synthesis. But, $F$ is a RDAA and causes increased production of both MN and ammonia. This effect might be related to the peptide amino acids which are more efficiently converted to cell protein than free amino acids. The production of ammonia was also faster by the peptides than the amino acids [24]. It was proposed that higher MN/DN, A+MN/DN $(0.49,0.92$, and $0.34,0.78$, respectively, for glucogenic and lipogenic diets) and lower Ammonia/DN (0.42, for glucogenic, and 0.44 for lipogenic diets) was the result of more accessibility of carbon skeletons and energy from fermentable carbohydrate for the conversion of nonprotein nitrogen like RDAA to microbial protein, and thus the supply of energy from glucogenic diets stimulated MN synthesis [25]. Greater $\mathrm{MN} / \mathrm{DN}$ and $\mathrm{A}+\mathrm{MN} / \mathrm{DN}$ (0.56 and 0.93, respectively) in SF, and lower Ammonia/DN (0.37) versus lower MN/DN and A+MN/DN (0.43 and 0.91, respectively) in Gr diets, and high Ammonia/DN (0.47) might be influenced by the unprocessed grains which are less degraded in the rumen, thereby resulting in the reduction of energy supply and MN synthesis [26]. This processing effect was similar to that recorded in cattle fed on barley grain diets subjected to different degrees of processing [27].

The maximum MN/DN in SFBSB and SFCSB could be due to structural and solubility characteristics of the protein found in soybean meal that make it easily attachable for ruminal microorganisms. This greater microbial protein synthesis was attributed to higher starch and $\mathrm{OM}$ digestion in the rumen for barley diets, Increasing starch digestibility in the rumen stimulated more microbial protein synthesis. There is an appropriate balance between starch digestion in the rumen and the intestine to support microbial protein synthesis as well as a moderate escape of starch to the duodenum [28]. Steam flaking may increase the feeding value of grains by enhancing starch digestibility in the rumen, produce more microbial protein and low amount of ammonia concentration in the rumen [20]. This may be related to the synchrony between ruminal protein and carbohydrate digestion. Microbial protein synthesis depends largely on the available amount and fermentation rate of carbohydrates and $\mathrm{N}$ in the rumen [29]. The results of the present study were consistent with those of a previous study pertaining to the reduction of in vitro ammonia concentrations with steam flaking. The earlier study cited also suggested that steam flake processing could improve ruminal fermentability and energy utilization by ruminants [30]. Our results from response surfaces showed that with increasing NFC, microbial protein synthesis increased as well (Figure 2). Also, with decreasing NDF, microbial production increased. Hristove et al. found that water soluble sugars caused a decrease in ammonia- $\mathrm{N}$ concentration in the rumen through the decreased production of ammonia; while starch increased the uptake 
Citation: Eyni B, Mesgaran MD, Vakili A, Valizadeh R (2017) In Vitro Yield of Microbial-N from Fermentation of Glucogenic and Lipogenic Diets Provided by Different Sources of Rumen Degradable Amino Acids. J Vet Sci Technol 8: 453. doi: 10.4172/2157-7579.1000453

Page 6 of 6

of ammonia for microbial protein synthesis [29]. The rate of substrate fermentation was roughly proportional to the rate of microbial growth, with more rapidly fermented substrates yielding more microbial mass. Stock et al. reported that increasing the proportion of nonstructural carbohydrate (NSC) and reducing the NDF of diets could result in higher yields of microbial protein [25].

\section{Conclusion}

This is the first study which highlighting the role of sources of rumen degradable amino acids in both glucogenic and lipogenic diets in rumen fermentation responses and microbial protein yield. In conclusion, the inclusion of Fortid as a rich source of the low molecular peptide with high rumen degradable amino acids used in both glucogenic and lipogenic diets was associated with in vitro high yield of rumen microbiota. This indicates that rumen degradable amino acids are a possible factor affecting microbial growth rate in the rumen. Although, glucogenic diets likely account for the high rate of rumen microbial growth, its possible that besides rumen degradable amino acids factors such as starch may also impact the microbial yield. The use of both steam flaked barley and corn, in overall, could provide higher rumen available energy compared with the milled grain, fermentation parameters obtained from gas production technique were improved. The results also underline the importance of glucogenic diets in contrast with regarding rumen fermentation responses.

\section{Acknowledgements}

This study was conducted in Ferdowsi University of Mashhad, Iran. Financial support for this study was provided by Pishgam Damparvar Sepahan ${ }^{\odot}$ and My Tech $^{\odot}$ companies.

\section{References}

1. Chang CF (2012) Carbohydrates. Comprehensive Studies on Glycobiology and Glycotechnology. 11th edn. InTech, p: 245-258.

2. Bach A, Ruiz Moreno M, Thrune M, Stern MD (2008) Evaluation of the fermentation dynamics of soluble crude protein from three protein sources in continuous culture fermenters. J Anim Sci 86: 1364-1371.

3. Brito AF, Broderick GA, Reynal SM (2007) Effects of Different Protein Supplements on Omasal Nutrient Flow and Microbial Protein Synthesis in Lactating Dairy Cows. J Dairy Sci 90: 1828-1841.

4. Hall MB, Larson CC, Wilcox CJ (2010) Carbohydrate source and protein degradability alter lactation, ruminal, and blood measures. J Dairy Sci 93: 311322 .

5. Neis EPJG, Dejong CHC, Rensen SS (2015) The Role of Microbial Amino Acid Metabolism in Host Metabolism. Nutrients 7: 2930-2946.

6. Mesgaran MD, Stern MD (2005) Ruminal and post-ruminal protein disappearance of various feeds originating from Iranian plant varieties determined by the in situ mobile bag technique and alternative methods. J Anim Feed Sci Technol 118: 31-46.

7. Beth Hall M (2013) Dietry starch source and protein degredability in diets containing source: Effect on ruminal measures and proposed mechanism for degredable protein effects. J Dairy Sci 96: 7093-7109.

8. Grings EE, Blummel M, Sudekum KH (2005) Methodological considerations in using gas production techniques for estimating ruminal microbial efficiencies for silage-based diets. J Anim Feed Sci Technol 124: 527-545.

9. Ørskov ER, McDonald I (1979) Estimation of protein degradability in the rumen from Incubation measurements weighted according to rate of passage. J Agricult Sci 92: 499-503.

10. Malekjahani F, Mesgaran MD, Vakili A, Sadeghi M, Yu P (2016) A Novel Approach to Determine Synchronization Index of Lactating Dairy Cow Diets with Minimal Sensitivity to Random Variations. J Anim Feed Sci Technol 22: 143-156.

11. Goering HK, Van Soest PJ (1970) Forage fiber analysis (apparatus, reagents, procedures, and some applications). In: Agricultural Handbook No. 379. USDAARS, Washington, DC, USA.
12. AOAC International (2000) Official Methods of Analysis. 18th edn. Gaithersburg, MD: AOAC International.

13. Van Soest PJ, Robertson JB, Lewis BA (1991) Methods of dietary fiber, neutral detergent fiber, and non-starch polysaccharides in relation to animal nutrition. J Dairy Sci 74: 3583-3597.

14. Higgs RJ, Chase LED, Ross A, Van Amburgh ME (2015) Updating the Cornell Net Carbohydrate and Protein System feed library and analyzing mode sensitivity to feed inputs. J Dairy Sci 98: 1-21.

15. SAS Institute Inc (1991) SAS/STAT User's Guide: Version 9.1. SAS Institute Inc., Cary, NC.

16. Van Soest PJ, Sniffen CJ, Mertens DR, Fox DG, Robinson PH, et al. (1982) A net protein system for cattle: The rumen submodel for nitrogen. In: Protein requirements for cattle: Proceedings of an International Symposium. Owens FN (ed.), MP- 109. Stillwater, Okla.: Division of Agriculture, Oklahoma State University, USA.

17. Dhanoa MS, Lopez S, Dijkstra J (2000) Estimating the extent of degradation of ruminant feeds from a description of their gas production profiles observed in vitro: Comparison of models. Br J Nutr 83: 131-142.

18. DePeters EJ, Getachew G, Fadel JG, Zinn RA, Tylor SJ, et al. (2003) In vitro gas production as a method to compare fermentation characteristics of steamflaked corn. J Anim Feed Sci Technol 105: 109-122.

19. Tamminga S, Luteijn PA, Meijer M (1997) Changes in composition and energy content of live weight loss in dairy cows with time after parturition. Livest Prod Sci 52: 31-38.

20. Argyle JL, Baldwin RL (1989) Effects of amino acids and peptides on rumen microbial growth yields. J Dairy Sci 72: 2017-2027.

21. Maia RGM, Chaudhary LC, Bestwick CS, Richardson AJ, McKain N, et al (2010) Toxicity of unsaturated fatty acids to the biohydrogenating ruminal bacterium, Butyrivibrio fibrisolvens. BMC Microbiol 10: 52 .

22. Nitipot $P$, Sommart K (2003) Evaluation of Ruminant Nutritive Value of Cassava Starch Industry by Products, Energy Feed Sources and Roughages Using in vitro Gas Production Technique. Proceeding of Annual Agricultural Seminar for year; 27-28 January, KKU, pp: 179-190.

23. May ML, Quinn MJ, DiLorenzo N, Smith DR, Galyean ML (2011) Effects of roughage concentration in steam-flaked corn-based diets containing wet distillers grains with solubles on feedlot cattle performance, carcass characteristics, and in vitro fermentation. J Anim Sci 89: 549-559.

24. Satter LD, Slyter LL (1979) Effect of ammonia concentration on rumen microbial protein production in vitro. Br J Nutr 32: 199-208.

25. Stokes SR, Hoover WH, Miller TK (1991) Impact of carbohydrate and protein level on bacterial metabolism in continuous culture. J Dairy Sci 74: 860-870.

26. Askar AR, Guadaa JA, Gonzalez JM, de Vega A, Fondevil M (2008) Rumen digestion and microbial protein synthesis by growing lambs fed highconcentrate diets: Effects of cereal processing and animal age. J Anim Feed Sci Technol 142: 292-305.

27. Beauchemin KA, Yang WZ, Rode LM (2001) Effects of barley grain processing on the site and extent of digestion of beef feedlot finishing diets. J Anim Sci 79 : 1925-1936.

28. Oba M, Allen MS (2003) Effects of diet fermentability on efficiency of microbial nitrogen production in lactating dairy cows. J Dairy Sci 86: 195-207.

29. Hristov AN, Ropp JK, Grandeen KL, Abedi S, Etter RP, et al. (2005) Effect of carbohydrate source on ammonia utilization in lactating dairy cows. J Anim Sci 83: 408-421.

30. Theurer CB, Swingle RS, Wanderley RC, Kattnig RM, Urias A, et al. (1999) Sorghum grain flake density and source of roughage in feedlot cattle diets. $J$ Anim Sci 77: 1066-1073. 